\title{
Consent procedures in pediatric biobanks
}

\author{
Noor AA Giesbertz ${ }^{1}$, Annelien L Bredenoord ${ }^{\star 1}$ and Johannes JM van Delden ${ }^{1}$
}

The inclusion of children's samples in biobanks brings forward specific ethical issues. Guidelines indicate that children should be involved in the consent procedure. It is, however, unclear how to allocate an appropriate role for children. Knowledge of current practice will be helpful in addressing this issue. Therefore, we conducted an international multiple-case study on the child's role in consent procedures in pediatric biobanks. Four biobanks were included: (1) LifeLines, (2) Prevention and Incidence of Asthma and Mite Allergy (PIAMA), (3) Young-HUNT3 and (4) the Oxford Radcliffe Biobank contribution to the Children's Cancer and Leukaemia Group tissue bank (ORB/CCLG). Four themes linked to the child's role in the consent procedure emerged from the multiple-case study: (1) motives to involve the child, (2) informing the child, (3) the role of dissent, assent and consent and (4) voluntariness of children to participate. We conclude that biobank characteristics influence the biobank's motives to include children in the consent procedure. Moreover, the motives to include children influence how the children are involved in the consent procedure, and the extent to which children are able to make voluntary decisions as part of the consent procedure. This insight is valuable when designing pediatric biobank governance.

European Journal of Human Genetics (2015) 23, 1129-1134; doi:10.1038/ejhg.2014.267; published online 24 December 2014

\section{INTRODUCTION}

A biobank can be defined as a collection of human biological material, stored for biomedical scientific research purposes, and is usually linked to phenotypic data. ${ }^{1,2}$ Pediatric biobanks are considered important for improving (children's) health care. ${ }^{3-8}$ However, the inclusion of children in biomedical research in general and pediatric biobanks in particular gives rise to specific ethical dilemmas. ${ }^{9-11}$ Children form a special group within biomedical research. They are usually considered incompetent to make an autonomous decision on research participation owing to their immaturity. ${ }^{12}$ Generally, parents (or legally authorized guardians) must give permission before children may be included. Ethical and legal guidelines indicate that children should be involved in the consent procedure as well. ${ }^{13-15}$ The Code of Federal Regulations, for example, states that adequate provisions must be made for soliciting assent from children. ${ }^{14}$ The WMA Declaration of Helsinki does not mention children specifically, but states that when the research subject, who is incapable of giving informed consent, is able to give assent it should be sought, and that dissent should be respected. ${ }^{13}$ The few biobanking guidelines that refer specifically to pediatric biobanks frequently allocate a certain role for the child in the consent procedure as well. ${ }^{1,16,17}$ Furthermore, several empirical studies about biobank participation show that generally children want to be involved in the decision-making procedure about the inclusion of their material in the biobank. ${ }^{18-20}$ It is, however, unclear how to allocate an appropriate role for children for the inclusion of their samples in biobanks. Knowledge of current practice will be helpful in addressing this issue. Presently, little is known on the children's role in consent in pediatric biobanking practice, only that children's opinions are indeed frequently (planned to be) sought, ${ }^{6,21}$ and that there is a considerable variability in consent forms ${ }^{22}$ and the forms can be confusing. ${ }^{23}$ However, to our knowledge, there are no studies that analyzed consent procedures and the child's role in depth.
We conducted a multiple-case study on the child's role in the consent procedures of four biobanks that include pediatric samples. Our study aims to provide insight into normative decisions and practical solutions biobanks develop in the pediatric context. This valuable information can be used to determine and assign an appropriate role for children in the consent procedure in pediatric biobanking. Moreover, considering the variety of types of biobanks, it is useful to examine whether biobank characteristics influence how to allocate an appropriate role for children, and if so, what this influence is.

\section{METHODS}

The case study method enables investigating a phenomenon in depth. ${ }^{24} \mathrm{We}$ studied the whole range of aspects that are part of the consent procedure, ranging from information provision to the consideration of the child's opinion.

\section{Case selection}

Four biobanks with diverse characteristics are included: (1) LifeLines, a population cohort from the Netherlands, ${ }^{25}$ (2) Prevention and Incidence of Asthma and Mite Allergy (PIAMA), a birth cohort study from the Netherlands, ${ }^{26}$ (3) Young-HUNT3, the adolescent part of the third wave of the population based Health Study of Nord-Trøndelag, Norway (the HUNT study $)^{27}$ and (4) the Oxford Radcliffe Biobank contribution to the Children's Cancer and Leukaemia Group tissue bank, in this paper referred to as ORB/ CCLG, a residual pediatric oncology tissue bank in the United Kingdom.

\section{Data collection}

After receiving permission from the biobank officials/management, data were collected from multiple sources in each biobank. Data were collected from November 2012 until August 2013. The biobank features and (consent) policies were outlined by studying textual sources such as websites, information leaflets and informed consent forms. Furthermore, observations were made, for example, during informed consent conversations or during medical measurements. Also, interviews were conducted to supplement previous collected information and to provide context. For each biobank, six to ten people were

\footnotetext{
${ }^{1}$ Department of Medical Humanities, Julius Center, University Medical Center, Utrecht, The Netherlands

*Correspondence: Dr AL Bredenoord, Department of Medical Humanities, Julius Center, University Medical Center Utrecht, Office Stratenum 6.131, PO Box 85500, 3508 GA Utrecht, The Netherlands. Tel: +31 8875 51351; Fax: +31 8875 68099; E-mail: a.I.bredenoord@umcutrecht.nl
}

Received 9 June 2014; revised 17 September 2014; accepted 30 October 2014; published online 24 December 2014 
interviewed (three interviews were conducted over the phone). Respondents were purposively sampled and approached in cooperation with biobank officials. An information letter regarding the case study and the interview was provided to potential participants. The information letters were formulated specifically for biobank staff, parents and children, respectively. Our main focus was interviewing people with knowledge of (the construction of) the child protocol, the consent/assent procedure and people with practical experience in the field. However, other stakeholders were included as well when possible, for example, participating children and parents. Except for one child and one research nurse, all persons approached consented to participation. A total of 29 people were interviewed (see Table 1).

\section{Data analysis}

The aim of this multiple-case study is to provide insight into normative decisions and practical solutions for consent-related issues in the pediatric context. In addition, it aims to examine whether biobank characteristics influence how to allocate an appropriate role for children in the consent procedure. To reach this goal, first each biobank, its characteristics and consent procedure were described (see Tables 2 and 3). Next, two analytic techniques were used: pattern matching and explanation building. ${ }^{28}$ Pattern matching involves comparison of the empirically based pattern with a predictive one. In this study, we expected that biobanks would show similarities and differences in their consent procedures and the role they attributed to the child in this procedure. In addition, the explanation building technique was used. The goal of this technique is to explain a phenomenon, that is, describe how or why

Table 1 Interview respondents' characteristics

\begin{tabular}{lc}
\hline & $n=29$ \\
\hline Biobank official & 11 \\
Research nurse/assistant & 6 \\
Researcher & 3 \\
Parent & 3 \\
Child & 6 \\
\hline
\end{tabular}

something happened. ${ }^{28}$ In this study, we want to explain the similarities and differences between the consent procedures of the biobanks. For this, NG coded all the data in NVivo 10 by labeling units of texts that were relevant to our research aim. ${ }^{29}$ ALB read the coded data and checked the codes for consistency. The codes were adjusted through discussion within the whole research group and by constant comparison across the cases and different data sources. When consensus was reached, themes were developed. Each theme was analyzed both within a single case and across cases. By analyzing the themes across cases, we aimed to gain insights into the influence of biobank characteristics on the child's role in the consent procedure. The results of the case description are presented in Tables 2 and 3, the themes that form the in-depth analysis of this study, are presented in the Results section.

\section{Ethical approval}

The project was evaluated in the Netherlands by the Research Ethics Committee (REC) of the University Medical Center Utrecht. In addition, the inclusion of Young-HUNT3 was assessed by the REC Central Norway. Both RECs exempted the project from further ethical scrutiny. The inclusion from ORB/ CCLG was evaluated by the Inter Divisional Research Ethics Committee from the University of Oxford and ethical approval was obtained.

\section{RESULTS}

Four themes linked to a child's role in the consent procedure in pediatric biobanking emerged from the data.

\section{Theme 1: Motives to involve the child}

Three types of motives for biobanks to involve the child in the consent procedure can be recognized in the cases. First, the wish to adhere to regulation that is aimed at the involvement of children in the decisionmaking procedure functions as a motive to involve children in all cases. In all three countries, national law requires involvement of children, although they differ in their exact requirements. ${ }^{30-33}$ Sometimes regulation is primarily aimed at clinical research and therefore not always considered appropriate for (longitudinal) biobank research. Other institutions, for example RECs, regularly offer guidance or instruct biobanks on the implementation of legal requirements in

Table 2 Case characteristics

\begin{tabular}{|c|c|c|c|c|}
\hline & LifeLines & PIAMA & Young-HUNT3 & $O R B / C C L G$ \\
\hline Country & Netherlands & Netherlands & Norway & United Kingdom \\
\hline Type & $\begin{array}{l}\text { A three-generation population } \\
\text { based cohort study }\end{array}$ & Birth cohort study & $\begin{array}{l}\text { Cross-sectional survey, with } \\
\text { possibility for follow-up }\end{array}$ & Tissue bank with residual tumor samples \\
\hline Participants & $\begin{array}{l}\text { Aim is to include } 165000 \text { partici- } \\
\text { pants, of which } 15000 \text { children } \\
0-18 \text { years. Official number will } \\
\text { follow in } 2014 \text {. Children included } \\
\text { between } 2010 \text { and } 2013\end{array}$ & $\begin{array}{l}\text { Baseline consists of } 3963 \text { children born } \\
\text { between } 1996 \text { and } 1997\end{array}$ & $\begin{array}{l}8677 \text { adolescents ( } 13-19 \text { years) } \\
\text { included between } 2006 \text { and } \\
2008\end{array}$ & $\begin{array}{l}\text { Patients from the John Radcliffe hospital } \\
\text { with a suspected diagnosis of a pediatric- } \\
\text { type solid cancer. The cooperation } \\
\text { started in 2009. Estimation: 10-30 } \\
\text { patients per year provide consent }\end{array}$ \\
\hline $\begin{array}{l}\text { Research } \\
\text { protocol }\end{array}$ & $\begin{array}{l}\text { Questionnaire parent, question- } \\
\text { naire children } \geq 13 \text { years, clinical } \\
\text { tests children } \geq 8 \text { years. Follow- up } \\
\text { every } 5 \text { years }\end{array}$ & $\begin{array}{l}\text { Part 1: Research aimed at mite allergy } \\
\text { and asthma. Children followed up to } 8 \\
\text { years with questionnaires for parents and } \\
\text { clinical tests in subgroups at } 1,4 \text { and } 8 . \\
\text { Residual blood from the newborn } \\
\text { screening was used. Part } 2 \text { : Extension of } \\
\text { follow-up to } 16 \text { years. Research goal } \\
\text { broadened to chronic diseases. Clinical } \\
\text { tests (at } 11 / 12 \text { years and } 15 / 16 \text { years) } \\
\text { and questionnaires parents and children }\end{array}$ & $\begin{array}{l}\text { Questionnaires, clinical tests } \\
\text { and short interview at school. } \\
\text { Phase } 2 \text { studies in subgroups: } \\
\text { physical fitness, acne, sight or } \\
\text { social anxiety }\end{array}$ & $\begin{array}{l}\text { Residual tissue (from a diagnostic or } \\
\text { therapeutic sampling procedure) is } \\
\text { stored in the tissue bank. Blood sample } \\
\text { taken during routine blood tests }\end{array}$ \\
\hline $\begin{array}{l}\text { Biological } \\
\text { material }\end{array}$ & Blood and urine samples & $\begin{array}{l}\text { Blood samples, nasal epithelial cells, } \\
\text { DNA swabs }\end{array}$ & Buccal swabs & Tumor tissue and blood samples \\
\hline Inclusion & $\begin{array}{l}\text { Through parents who participate in } \\
\text { LifeLines }\end{array}$ & Through pregnant women & Through schools & Through hospital staff \\
\hline
\end{tabular}




\section{Table 3 Description of consent procedures}

LifeLines Parents participating in LifeLines receive an invitation for their child to participate. After parental agreement, the family receives a letter, an information folder for parents and an informed consent form that must be signed by at least one parent. A children's information brochure is added for children $\geq 8$ years. An informed consent form for the child is added for children $\geq 12$ years. By returning the signed informed consent form(s) to Lifelines, parents receive a questionnaire and/or an invitation for screening of the child on location

PIAMA

For the first part of the PIAMA project, pregnant women must provide written consent for the inclusion of their child. Both parents must provide written consent for clinical tests at 1, 4 and 8 years old. Parents need to provide additional written consents for, among other things, the use of residual blood from the newborn screening (for an IgE measurement) and additional measurements in former blood samples (glucose, HbAlc, cholesterol). For the second part of the PIAMA project, families receive, when the children are 11/12 years, an invitation letter, information material (both for parents and children), a consent form for the parents and a separate form for children $\geq 12$ years. The signed consent form(s) must be returned to PIAMA. When the children are 15/16 years, families receive two invitation letters (one addressed to the parent and one to the child), combined information material for parents and child, a combined consent form that needs to be signed by the parents and child. One parent may sign at home, the other parent and the child must sign at location after an informed consent conversation

Young-HUNT3 HUNT provides information to the schools/teachers and the school board must give permission for participation of the school in HUNT. Subsequently, the teachers inform the students in the class and hand out the information brochure for the children to take home and to discuss it with their parents. Consent must be signed by at least one of the parents and returned to the school. The child needs to sign a consent form at the time of the questionnaire (in the class). Before and after the clinical tests, the nurse asks whether the children have questions. If children want to participate, but the parents do not give consent, the children may participate in the questionnaire/tests; however, in that case the data will not be saved

ORB/CCLG First, a consultant or research nurse gives a verbal explanation to patients and parents. Thereafter, written information is handed out (both for the child and the parents). Later, patient and parents must sign the consent forms. It depends on the child's capacities and wishes whether the child and/or the parents must sign an assent/consent form

practice. Moreover, it is articulated that rules cannot be comprehensive and that the actual involvement of the child depends highly on how people act in practice.

You have to be convinced that this is something the child wants. But, that's also up to the people who work with the children. Rules cannot be all-embracing. (Interview 27)

Second, involvement of the child is considered to have a positive effect on her participation in the research. Particularly, biobanks that solicit a contribution from their participants at a later stage put forward that it would have a positive effect on continuous participation.

We prefer that they come back in the future for follow-up measurements rather than they quit right now, cause then we would have nothing. So if the child doesn't want a venipuncture, we don't do it. (Interview 26)

Third, the motive of respecting the child as a person, in influencing how to involve children in decision making can be recognized in all cases. Biobank staff consider it self-evident to involve children in the consent procedure, as it is the child's material that is included in the biobank.

We don't want to take advantage of children. We don't want them to do something that they don't want to do. (Interview 10)

Moreover, respondents from the biobank that includes residual tissue from pediatric oncology patients indicate that involving children can contribute to an overall feeling of trust in the hospital and feeling of control.

\section{Theme 2: Informing the child}

Three cases have written information for children at the time of their inclusion. The birth cohort study provides written information at a later stage. The information usually covers research procedures and basic information on the storage of data and/or samples. A difference in information content is whether it is clearly mentioned that children can withdraw their data and/or material at a later stage, which is possible in all four biobanks.

Biobank staff from all cases consider verbal information an important method to inform children (and their parents). Some put forward that written information is actually supportive for verbal explanation.

From my experience of consenting, a lot of your work is done via conversation. And so, if you have a brief document like that, people can quickly read it and will generate their own questions on the back of that. (Interview 5)

Although not all biobank protocols specifically require personal verbal explanation by biobank employees, in all four cases oral clarification or description of the biobank was given. However, our observations show there is variety in the content and the amount of effort biobank employees put into informing children personally. Moreover, in several biobanks a leading role was attributed to the parents. Although the parental role is considered important for informing children, respondents also noted that in practice children are regularly poorly informed by the parents and that it is left to the biobank employees to correct this. Furthermore, the timing of verbal explanation differs between the biobanks: first time personal contact with biobanks employees is scheduled before, during or after the child and/or parent sign the consent form.

\section{Theme 3: The role of dissent, assent and consent}

Dissent, assent and consent are linked to a child's expression of her opinion. These three concepts played a role at the time of the child's inclusion in three cases. In the birth cohort study, the concepts become apparent at a later stage. In line with established international norms, all biobanks mention in written sources that if a child does not want to participate, this should be respected, which refers to dissent. 
During the medical examination the participant can stop participating at any given moment. (Project proposal approved by REC)

However, it is not always clear how a child's dissent is respected in practice (see theme 4). In contrast, sometimes children's refusal is given considerable weight and can even influence biobank policy. In three cases, children's refusal to blood withdrawal, or possible refusal, had an effect on research protocols. As children could refuse participation altogether, blood samples were made an optional part of biobank participation or left out.

We noticed that people were inclined to refuse participation because of the blood sample. Since there are a lot of other tests that are of interest to use, we said that if the child does not want to participate in one or more parts of the study, this could be indicated and then we would discuss whether the child wants to participate in the other tests. (Interview 18)

Besides a child's refusal, all cases pay attention to (the need to obtain) a child's agreement or permission, which is usually referred to as assent and consent. The actual implementation of assent and consent differs between biobanks. An important reason for this diversity is the variation between national laws and the instructions of formal organizations like RECs. Prominent differences are the use of age limits and/or individual competency assessments. The Human Tissue Act in the United Kingdom states that appropriate consent should be obtained from children for the use of tissue in research. ${ }^{31}$ This means obtaining consent from the child when he is competent to deal with that issue. It is commonly assumed that the principle of 'Gillick competence' can be applied here, whereby children with sufficient maturity to make a decision can give consent on their own behalf. ${ }^{34-36}$ When a young person is believed to be competent, consent from those with parental responsibility is not legally necessary for use of biological samples in research. However, in practice, the involvement of parents in decision-making will probably be required by most RECs. ${ }^{34,35}$ In contrast, it is required by Dutch law that children $\geq 12$ years provide written consent. ${ }^{30}$ The Norwegian law also mentions age limits, although it also specifically states that as the child grows older and more mature, increasing importance should be attached to her opinion. ${ }^{32,33}$

\section{Theme 4: Voluntariness of children to participate}

Children participate in biobanks for different reasons. There seems to be a continuum from pressure/coercion, complying with parental wishes, echoing parents and having personal altruistic feelings. It appears that both researchers and parents can put pressure on the child to participate in the biobank.

I have seen that some parents, when their children start crying with the blood withdrawal, say 'just do it'. (Interview 13)

She [the research nurse] said 'Let's see if I can talk him into it'... But I thought if she pushes him, and he really doesn't want to, I would stop her. (Interview 22)

The next step on the scale is compliance of the child with their parents' wishes. It is difficult to make a clear distinction between pressure and compliance, but compliance may indicate that the children are at least not against participation. Also, some children stated that they participate to help other children. However, several respondents questioned whether these are the children's own words or their parents'.

\section{DISCUSSION}

The results show that all four cases attribute a role for children in the consent procedure. The exact implementation (themes 2 and 3 ) is affected by biobank motives to involve children in the consent procedure (theme 1). In turn, the exact implementation of the role for children influences the extent to which children are able to make voluntary decisions as part of the consent process (theme 4). Thus the motives to involve children appear to be leading for biobanks when they consider the role for children in the consent procedure. The following remarks can be made about the effect and interplay of the three motives achieved in this case study.

For all cases the wish to adhere to regulation is an important motive to involve children in the consent procedure. Although regulation applied to all cases, the actual involvement of children varied because rules and regulation content differs, such as the differences in the use of age limits (see theme 3). However, not all variation can be explained by the variety of rules. How people act in practice depends on the interpretation of rules, ${ }^{37}$ which may (at least partly) be influenced by underlying motives. This case study shows that two other motives to involve children in the consent procedure, research interests and respect for the child, are of importance here.

Several cases in this study emphasize a child's freedom to refuse blood withdrawal, as it may otherwise result in the refusal of the child's continuous participation in the biobank altogether. Hence, this is a clear research interests motive to involve children in the consent procedure. This finding resonates with the widely held view that, in general, biobank interests run parallel with those of the participants. As continuous participation is essential for the success of biobank research, biobank governance is often committed to gaining and maintaining trust of the participants and related issues such as privacy and consent. ${ }^{38-41}$ The research interests motive to involve children is clear for biobanks which seek follow-up efforts from children. ${ }^{19}$

All cases emphasize respect for the child as a motive, which refers to the intrinsic motivation to involve children in the consent procedure. Thus, for the biobanks that solicit follow-up efforts from children, both research interests and respect for the child are underlying motives to involve the child in the consent procedure. When the actual involvement of the child is considered, the two motives go hand in hand. However, this is true up to a certain point. There is a difference between involving children out of research interests or out of respect for children. For example, although it is theoretically possible for children to withdraw their (not used) biological samples in all cases, this is not always communicated clearly. From a research interests perspective, this may be rational, whereas from a respect for the child point of view, this would be inappropriate.

Furthermore, biobanks that seek only a one-off effort from children do not have a clear research motive to involve children in the consent procedure, such as the residual tissue biobank in this case study. In this particular case, multiple respondents articulate a strong motivation to include the children in the consent procedure, as they want to generate a feeling of trust and control for the children. Particularly, because the children in this biobank are part of a very vulnerable group in a hospital. However, as we only studied one 'one-off effort' biobank, it may be possible that there are biobanks that do not have, or only to a minimal extent, respect for the child as an underlying motive to involve children. As there is no underlying research motive for these biobanks either, the role for children in the consent procedure may come under pressure. 


\section{Good pediatric biobanking principles}

In our opinion, the motive of respecting the child as a person should be the main motive when the role for children in the consent procedure is considered. This would, for example, mean that a child's right to withdraw must always be clearly articulated. The motive of respecting the child is connected to treating the child as an individual, recognizing the child's rights to be involved in matters that affect her and to express her personal views, as articulated by the United Nations Convention on the Rights of the Child. ${ }^{42}$ Earlier we have argued that involving children in accordance with their capabilities and wishes does justice to the characteristics of childhood. ${ }^{43}$

Regulation offers guidance and protection of the child's right to be involved and is therefore of great importance. The European Society of Human Genetics (ESHG), for example, recently stated in their principles for good practice in pediatric biobanking that children should be informed and that assent should be obtained and dissent should be respected. ${ }^{17}$ However, presently, there is no consistent legal framework for biobanking in Europe. ${ }^{44}$ In addition, even when such a framework is developed, regulation alone cannot guarantee appropriate involvement of the child, ${ }^{37}$ as is also shown in this case study. Therefore, we add that when biobanks take children seriously as persons, these principles should be operationalized from a 'respect for the child' point of view in all layers of the biobank organization.

Our study has some limitations. Although biobanks with different characteristics are included, not all potential characteristics are represented. In addition, a limited number of observations are made of consent procedures, as they did not always take place at the time of the study. Furthermore, part of the study concerns historical research and interview respondents may have altered recollections of the situation. However, by combining different types of sources we aimed to achieve as complete an image of pediatric biobanks as possible. Since the focus of this paper is the inclusion of children, the issue of recontacting the child at maturity to obtain her consent (or give the opportunity to withdraw) was not discussed. This important topic, however, should be addressed in future work.

\section{CONCLUDING REMARKS}

Regulation is important to protect a child's right to be involved in the consent procedure. The actual involvement of the child, however, depends on the underlying motives. For 'one-off effort' biobanks there is no clear research motive to involve children. It is essential for these biobanks to implement governance mechanisms that emphasize the importance of respect for the child. For 'follow-up effort' biobanks, the promotion of research interests is a strong incentive to involve children in the consent procedure. Although for these biobanks research interests go hand in hand with the child's interests, this is only to a certain extent and respect for the child should be the main motive.

In sum, different biobank models lead to a different involvement of children in the consent procedure. This is a valuable insight when designing pediatric biobank governance. Involving children in the consent procedure does not only respect the children but it also contributes to the sustainable development of biobanks in general.

\section{CONFLICT OF INTEREST}

The authors declare no conflict of interest.

\section{ACKNOWLEDGEMENTS}

We thank the four biobanks: LifeLines, PIAMA, HUNT and ORB/CCLG, and the biobank employees, parents and children for their participation in our study. In addition, we also thank Professor Jane Kaye, Dr Karen Melham,
Dr Maria C Stuifbergen and Dr Marijke C Kars for their support in conducting this case study. We acknowledge funding from ZonMw - The Netherlands Organization for Health Research and Development, project no. 113203013.

1 Organisation for Economic Co-Operation and Development: OECD Guidelines on Human Biobanks and Genetic Research Databases. Paris: OECD, 2009.

2 Council of Europe, Committee of Ministers: Recommendation Rec(2006)4 of the Committee of Ministers to Member States on Research on Biological Materials of Human Origin. Strasbourg: Council of Europe, 2006.

3 Kaiser J: Genetics. U.S. hospital launches large biobank of children's DNA. Science 2006; 312: 1584-1585.

4 Vogel G: Genetics. Biobank ties cancer genes to rare developmental syndrome. Science 2006; 311: 456

5 Brisson AR, Matsui D, Rieder MJ, Fraser DD: Translational research in pediatrics: tissue sampling and biobanking. Pediatrics 2012; 129: 153-162.

6 Salvaterra E, Giorda R, Bassi MT, et al: Pediatric biobanking: a pilot qualitative survey of practices, rules, and researcher opinions in ten European Countries. Biopreserv Biobank 2012; 10: 29-36.

7 Barnes MG, Lynch JA, Corsmo JJ, Witte DP, Steele PE: Biobanking in pediatric research; in Hutton J (ed): Pediatric Biomedical Informatics. Computer Applications in Pediatric Research. Dordrecht, Netherlands: Springer, 2012, Vol 2, pp 109-129.

8 Lindroth AM, Plass C: Recurrent H3.3 alterations in childhood tumors. Nat Genet 2013; 45: 1413-1414.

9 Caldwell PH, Dans L, de Vries MC, et al: Standard 1: consent and recruitment. Pediatrics 2012; 129: S118-S123.

10 Pedersen M, Merlo DF, Knudsen LE: Ethical issues related to biomonitoring studies on children. Int J Hyg Environ Health 2007; 210: 479-482.

11 Hens K, Nys H, Cassiman JJ, Dierickx K: Risks, benefits, solidarity: a framework for the participation of children in genetic biobank research. J Pediatr 2011; 158: 842-848.

12 Leikin S: Minors' assent, consent, or dissent to medical research. IRB 1993; 15: $1-7$.

13 World Medical Association (WMA): WMA Declaration of Helsinki-Ethical Principles for Medical Research Involving Human Subjects. Fortaleza: WMA, 2013.

14 US Department of Health and Human Services (HHS): Human Subject Research (45 CFR 46, Subpart D). Protections for Children involved as Subjects in Research. Washington, DC: HHS, 2009.

15 Council for International Organizations of Medical Sciences (CIOMS): International Ethical Guidelines for Biomedical Research Involving Human Subjects. Geneva: CIOMS, 2002.

16 Hens K, Nys H, Cassiman JJ, Dierickx K: Biological sample collections from minors for genetic research: a systematic review of guidelines and position papers. Eur J Hum Genet 2009; 17: 979-990.

17 Hens K, Van El CE, Borry P, et al: Developing a policy for paediatric biobanks: principles for good practice. Eur J Hum Genet 2013; 21: 2-7.

18 van der Pal S, Sozanska B, Madden D, et al: Opinions of children about participation in medical genetic research. Public Health Genom 2011; 14: 271-278.

19 Swartling U, Hansson MG, Ludvigsson J, Nordgren A: My parents decide if I can. I decide if I want to. Children's views on participation in medical research. J Empir Res Hum Res Ethics 2011; 6: 68-75.

20 Hens K, Nys H, Cassiman JJ, Dierickx K: The storage and use of biological tissue samples from minors for research: a focus group study. Public Health Genomics 2011; 14: 68-76.

21 Ries NM, LeGrandeur J, Caulfield T: Handling ethical, legal and social issues in birth cohort studies involving genetic research: responses from studies in six countries. BMC Med Ethics 2010; 11: 4.

22 Dove ES, Avard D, Black L, Knoppers BM: Emerging issues in paediatric health research consent forms in Canada: working towards best practices. BMC Med Ethics 2013; 14: 5.

23 Weir RF, Horton JR: Genetic research, adolescents, and informed consent. Theor Med 1995: 16: 347-373.

24 Yin RK: Introduction: how to know whether and when to use case studies as a research method; in Yin RK (ed): Case Study Research: Design and Methods, 4th edn. Thousand Oaks, CA, USA: Sage Publications, 2009, Vol 5, pp 3-23.

25 Stolk RP, Rosmalen JG, Postma DS, et al: Universal risk factors for multifactorial diseases: LifeLines: a three-generation population-based study. Eur J Epidemiol 2008; 23: 67-74.

26 Wijga AH, Kerkhof M, Gehring U, et al: Cohort profile: The Prevention and Incidence of Asthma and Mite Allergy (PIAMA) birth cohort. Int J Epidemiol 2014; 43: 527-535.

27 Holmen TL, Bratberg G, Krokstad S, et al: Cohort profile of the Young-HUNT Study, Norway: a population-based study of adolescents. Int J Epidemiol 2014; 43: 539-544.

28 Yin RK: Analyzing case study evidence: how to tart your analysis, your analytic choices, and how they work; in Yin RK (ed): Case Study Research: Design and Methods, 4th edn. Thousand Oaks, CA, USA: Sage Publictions, 2009, Vol 5, pp 127-163.

29 NVivo qualitative data analysis [computer program] Version 10. QSR International Pty Ltd, 2012.

30 Wet Medisch Wetenschappelijk Onderzoek met Mensen Article 6. [Medical Research involving Human Beings], Revised 2012. Available at: http://wetten.overheid.nl/ BWBR0009408/geldigheidsdatum_09-12-2013 (last accessed 9 December 2013). 
31 Human Tissue Act. Chapter 30. Part 1 Section 2. 2004. Available at: http://www. legislation.gov.uk/ukpga/2004/30/section/2 (last accessed 9 December 2013).

32 Lov om medisinsk og helsefaglig forskning (helseforskningsloven), Chapter 4, §17 and \$18. [the Health Research Act], Revised 2013. Available at: http://lovdata.no/dokument/NL/lov/2008-06-20-44 (last accessed 12 December 2013).

33 Lov om pasient- og brukerrettigheter (pasient- og brukerrettighetsloven), § 4.4 [the Patient's Rights Act], Revised 2011. Available at: http://lovdata.no/dokument/NL/lov/ 1999-07-02-63 (last ccessed 12 December 2013).

34 Human Tissue Authority. Code of practice 1: Consent. Updated 2014. Available at: http://www.hta.gov.uk/_db/_documents/Code_of_practice_1_-_Consent.pdf (last accessed 3 September 2014).

35 Medical Research Council. Research and the Human Tissue Act - Consent. MRC Regulatory Support Centre 2007. Available at: http://www.mrc.ac.uk/research/ facilities/regulatory-support-centre/human-tissue/related-content/consent-summary/ (last accessed 3 September 2014).

36 McHale J, Habiba M, Dixon-Woods M, Cavers D, Heney D, Pritchard-Jones K: Consent for childhood cancer tissue banking in the UK: the effect of the Human Tissue Act 2004. Lancet Oncol 2007; 8: 266-272.
37 Bos W, Tromp K, Tibboel D, Pinxten W: Ethical aspects of clinical research with minors Eur J Pediatr 2013; 172: 859-866.

38 Gaskell G, Gottweis H: Biobanks need publicity. Nature 2011; 471: $159-160$.

39 Kaye J, Gibbons SMC, Heeney C, Parker M, Smart A: Governing Biobanks: Understanding the Interplay Between Law And Practice, 1 edn. Oxford, UK: Hart Publishing Limited, 2012.

40 Tutton R, Kaye J, Hoeyer K: Governing UK Biobank: the importance of ensuring public trust. Trends Biotechnol 2004; 22: 284-285.

41 Saha K, Hurlbut JB: Research ethics: treat donors as partners in biobank research. Nature 2011; 478: 312-313.

42 United Nations: Convention on the Rights of the Child. New York, NY, USA: United Nations, 1989.

43 Giesbertz NA, Bredenoord AL, van Delden JJ: Clarifying assent in pediatric research. Eur J Hum Genet 2013; 22: 266-269.

44 European Commision. Biobanks for Europe: A Challenge For Governance. Luxembourg: Expert Group on Dealing with Ethical and Regulatory Challenges of International Biobank Research, European Union, 2012. 